\title{
Antibiotic Use and Resistance Among Prescribers: Current Status of Knowledge, Attitude, and Practice in Egypt
}

This article was published in the following Dove Press journal: Infection and Drug Resistance

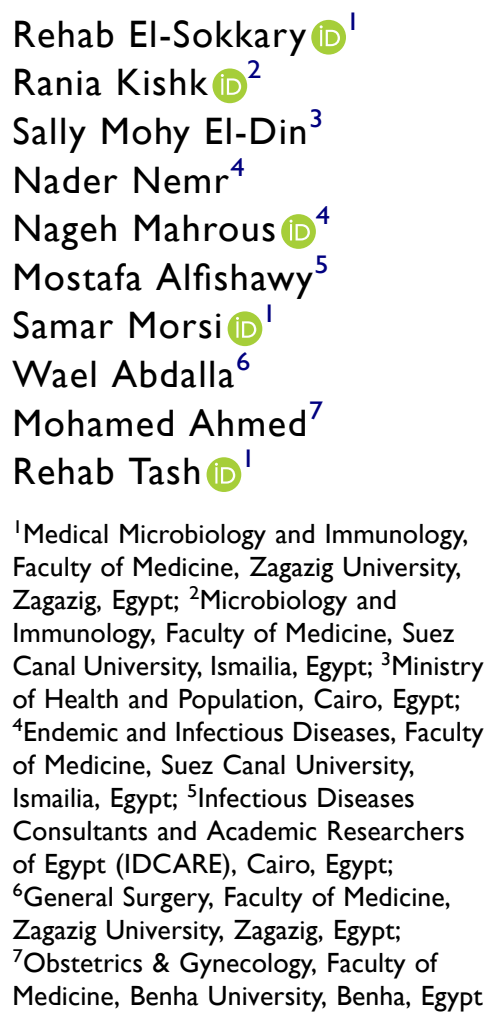

Correspondence: Rehab El-Sokkary

12 Abd Aziz Ali Street, Zagazig, Sharkeia, Egypt

Tel +201005650273

Fax +20 552307830

Email rehab_elsookary@yahoo.com
Introduction: The problem of antimicrobial resistance (AMR) is rising worldwide. One of the most significant factors influencing antimicrobial resistance in low- and middle-income countries is the lack of the skills and knowledge of health care providers for proper antimicrobial use.

Aim: To identify knowledge, characterize practices and describe the attitude of Egyptian prescribers towards antibiotic use.

Methods: A self-administered validated questionnaire was distributed among Egyptian prescribers.

Results: Five hundred Egyptian physicians responded to the questionnaire, 113 (22.6\%) reported having Antibiotic Stewardship Program (ASP) at their workplace, 99 (19.8\%) use international antibiotic guidelines as the main source for prescribing activity, $358(71.6 \%)$ recorded adequate knowledge. Elder prescribers and those who work in private or university hospitals were significantly more knowledgeable ( $\mathrm{p}=0.031$ and 0.001 , respectively). Forty-seven $(9.4 \%)$ showed a positive attitude towards proper antibiotic prescription. The type of work institution; primary health clinics and private, or university hospital and the specialty are significantly associated with a positive attitude ( $\mathrm{p}=0.009$ and 0.015 , respectively). Seventy-eight $(15.6 \%)$ expressed a proper antibiotic prescription practice. Elder age, more experienced and trained prescribers showed more proper practice. The implementation of ASP and using proper sources of information were significantly associated with proper practice ( $\mathrm{p}=0.012$ and 0.008 , respectively).

Conclusion: Egyptian prescribers have a good level of knowledge about antibiotics. However, low rates of positive attitude and proper practice towards the problem of AMR and ASP are recorded.

Keywords: antibiotics, resistance, stewardship, prescribers, multidrug resistance, low- and middle-income countries

\section{Introduction}

Antimicrobial drugs have been widely used in human medicine for more than 50 years either as prophylaxis or therapeutics, with tremendous benefits to human health. Unfortunately, widespread usage, misuse or inappropriate prescription have resulted in the emergence of drug-resistant microbes. ${ }^{1}$ According to World Health Organization (WHO) reports, more than $50 \%$ of all antibiotics are prescribed, sold or dispensed incorrectly. In addition, $50 \%$ of patients do not take antibiotics properly. ${ }^{2}$ Infections with drug-resistant bacteria have increased not only morbidity and mortality, but also length of hospitalization and care costs. ${ }^{3}$ 
Antibiotic use in medicine varies not only by medical condition, but also by geographical area associated with various health systems, culture and education, systemic elements of the primary care system and consumer characteristics. ${ }^{4}$ Field studies conducted in resourcepoor countries have highlighted a large degree of excessive use of drugs both in health facilities and in the community. This has gone a long way to add to the everincreasing cost of providing health care, particularly in the event of drug resistance. ${ }^{5}$ In order to ensure rational prescription of medications, prescribers must adopt the guidelines for treatment and must also follow the standard prescribing protocol. ${ }^{6}$ One of the most significant factors influencing antimicrobial resistance in low- and middle-income countries is the lack of the skills and knowledge required by health care providers for proper antimicrobial use. $^{7}$

Few scattered studies have been conducted in Egypt on antibiotic use among physicians in a single facility ${ }^{8,9}$ and undergraduate medical students. ${ }^{10}$ It is therefore important to resolve the issues of antibiotic usage among a wide range of prescribers to explore their possible position in the battle against irrational antibiotic use. To the best of our knowledge, this is the first national study that identifies knowledge, characterizes practices and describes the attitude of Egyptian prescribers towards antibiotic use.

\section{Materials and Methods}

\section{Study Setting and Design}

This study was carried out in Egypt, a country linking northeast Africa with the western part of Asia. Egypt is divided into 27 governorates and each has a capital and at least one city. Most governorates have a population density of more than one thousand per one kilometer. This cross-sectional, descriptive study of a representative sample of Egyptian Health Care Workers (HCWs) was conducted according to the international guidelines of Strengthening the Reporting for Observational Studies in Epidemiology, STROBE. The sample size required for the study was estimated to be 483 , with a power of $80 \%$ and a confidence level of $95 \%$. The study followed the principles of the Helsinki Declaration and ethical approval was obtained from the institutional review board of Zagazig University, Egypt. The completion of the questionnaire by participants was considered an agreement for participation in the study.

\section{Data Collection Tool}

A self-administered questionnaire was directed to health care personnel who prescribed antibiotics from 1st February 2020 to 30th April 2020. To develop the questionnaire, an in-depth literature review was carried out. ${ }^{3,6,8-10}$ An initial version of the questionnaire was drafted and then revised by the research team. The questionnaire had been piloted among a group of study participants to state all the amendments about language and simplicity of use, in addition to assess the practicability of the questionnaire. Their comments and suggestions were addressed accordingly. Data gathered from the pilot study were not included in final analysis.

This standardized questionnaire was divided into 4 sections. Section (1) included five items to provide information about the demographic and professional related data. Section (2) included four items to provide information about respondents' previous training concerning antibiotics stewardship, their source of information, the presence of Antibiotic Stewardship Program (ASP) and the application of WHO AWaRe classification of antibiotics at their workplaces "Access, Watch, Reserve groups". The third section included fourteen items to assess the participants' general knowledge on antibiotic resistance and use. Each question was answered by either yes, no, or do not know. Yes, was the correct answer to some questions and no for others. Section (4) included seventeen items to determine the respondents' attitude towards antibiotic resistance and prescription practices. Responses for the attitude section were recorded on the 5-point Likert scale as follows: strongly agree, agree, neutral, disagree, and strongly disagree. The fifth section included four items to identify the participants' practice in applying proper antibiotic prescription.

\section{Data Collection Process}

The questionnaire was distributed via different on-line applications, e.g., WhatsApp, Facebook and Messenger. A printed form was available and distributed. The title, aim and objectives of the study were clarified in the questionnaire form. Respondents were asked if they want to participate or not. A clear statement that their completion of the questionnaire implies their consent to participate was included in the form. We clarified that this survey was for research purpose. Data were collected anonymously. 


\section{Statistical Analysis}

All data were collected, tabulated, and statistically analyzed using SPSS version 19. Categorical qualitative variables were expressed as absolute frequencies (number) and relative frequencies (percentage). Categorical data were compared using Chi-square test ( $\chi 2$ test). All tests were two sided. p-value $<0.05$ was considered statistically significant (S), p-value $<0.001$ was considered highly statistically significant (HS), and $p$-value $\geq 0.05$ was considered statistically insignificant (NS). For assessing knowledge, a score of one point was given if the right answer was chosen and a score of zero was given if the wrong answer or 'do not know' was chosen. A total score ranged from " 0 " to " 28 ". Participants were grouped into 2 categories according to their level of knowledge: adequate ( $\geq 60 \%$ of total marks), and inadequate ( $<60 \%$ of total marks). For assessing attitude, a score of 5 to 1 was given to each item according to the selected point on Likert scale. Participants were grouped into positive or negative; $\geq 60 \%$ or $<60 \%$ of total marks, respectively. This giving a total score ranging from 17 to 85 . Attitude level $\geq 60 \%$ is considered as a positive attitude. For assessing practice, antibiotic prescription practice was calculated by giving one point for each selected step. This gave a score ranging from 1 to 4 . Practice level $\geq 60 \%$ is considered as proper practice. ${ }^{11}$

\section{Results}

A total of 500 Egyptian physicians were included in the study: 295 (59\%) males and 205 (41\%) females, with an age range from 25 to more than 50 years. Prescribers were distributed across the different types of Egyptian healthcare institutions, the highest percentage 222 (44.4\%) worked in Ministry of Health and population (MOHP) Hospitals, Table 1.

Out of the 500 respondents, 113 (22.6\%) reported they have ASP at their workplace and $67(13.4 \%)$ have lists of antibiotics classified into "Access, Watch, Reserve "groups.

The main sources of information about antibiotic resistance and ASP are international antibiotic guidelines 99 (19.8\%), advice from older colleagues 85 (17\%) and pharmaceutical companies 83 (16.6\%), Figure 1 .

Adequate knowledge is recorded for 358 (71.6\%) of the participants (Table 2). A statistically significant association was observed between adequate knowledge level and age $(\mathrm{X} 2=19.9, \mathrm{p}=0.031)$ and work institutions $(\mathrm{X} 2=19.9, \mathrm{p}=0.001)$, where elder prescribers and those who work in private or university hospitals were significantly more knowledgeable.

Forty-seven prescribers $(9.4 \%)$ showed a positive attitude towards proper antibiotic prescription, Table 3 . The majority $434(86.8 \%)$ agreed on the importance to identify the resistance rate at their workplace and $404(80.8 \%)$ expressed their needs to attend antibiotic training courses.

Most of them (70-80\%) agreed that frequent antibiotic prescription; mainly broad-spectrum antibiotics for the same patient, inappropriate doses, patient demand and poor infection control practices have a role in increase the burden of antimicrobial resistance. On the other hand, the majority $406(81.2 \%)$ consider that unindicated prescription of antibiotics does not cause harm. The type of work institution $(X 2=15.33, \mathrm{p}=0.009)$ and the specialty $(\mathrm{X} 2=10.52, \mathrm{p}=0.015)$ are significantly associated with a positive attitude, where the prescribers who work in primary health clinics, private Clinic or university showed a more positive attitude.

The antibiotic prescription rates among study participants were: 1-2 times per week for 65 (13\%), 3-5 times per week for $136(27.2 \%)$, once daily or more for 277 (55.4\%), once monthly for $8(1.6 \%)$, and once weekly for $14(2.8 \%)$ of them. Seventy-eight (15.6\%) participants expressed a proper antibiotic prescription practice. A high rate of prescribers $345(69 \%)$ order culture only when no improvement of the clinical condition is showed, $180(36 \%)$ consult the lab when there is no clinical response with the treatment regime. Practicing different prescription steps is presented in Figure 2.

The age $(\mathrm{X} 2=13.86, \mathrm{p}=0.001)$, experience years $(\mathrm{X} 2=11.65, \mathrm{p}=0.009)$ and training $(\mathrm{X} 2=9.46, \mathrm{p}=0.002)$ were presented as significant factors that affect the practice. Elder age, more experienced and trained prescribers showed more proper practice. The implementation of antimicrobial stewardship program $(\mathrm{X} 2=9.69, \mathrm{p}=0.008)$ and using proper sources of information $(\mathrm{X} 2=6.33, \mathrm{p}=0.012)$ were significantly associated with proper practice. A significant positive correlation between knowledge and attitude is present and also between knowledge and practice $(\mathrm{p}<0.005)$.

\section{Discussion}

The potential dangers associated with inappropriate use of antibiotics are the emergence and dissemination of resistant micro-organisms, and significant adverse effects such as increase in the duration of hospitalization, increase in the hazard of drug toxicity, and a significant increment in 
Table I Egyptian Antibiotics Prescribers' Demographic Characteristics, Professional and Institutional Information

\begin{tabular}{|c|c|c|c|c|c|}
\hline \multicolumn{2}{|l|}{ Items } & \multicolumn{4}{|l|}{ Specialty } \\
\hline & & \multirow{2}{*}{$\frac{\text { Medical } n=313}{149(47.6 \%)}$} & \multirow{2}{*}{$\begin{array}{l}\text { Surgery } \mathbf{n = | 4 |} \mid \\
42 \\
(29.8 \%)\end{array}$} & \multirow{2}{*}{$\begin{array}{l}\text { ER and ICU } \mathbf{n = 4 2} \\
12 \\
(28.6 \%)\end{array}$} & \multirow{2}{*}{$\begin{array}{l}\text { Others } n=4 \\
2 \\
(50.0 \%)\end{array}$} \\
\hline Gendre & Female & & & & \\
\hline & Male & $164(52.4 \%)$ & $\begin{array}{l}99 \\
(70.2 \%)\end{array}$ & $\begin{array}{l}30 \\
(71.4 \%)\end{array}$ & $\begin{array}{l}2 \\
(50.0 \%)\end{array}$ \\
\hline \multirow[t]{6}{*}{ Age (Years) } & \multirow[t]{2}{*}{$25-35$} & 183 & 85 & 28 & 4 \\
\hline & & $(58.5 \%)$ & $(60.3 \%)$ & $(66.7 \%)$ & $(100.0 \%)$ \\
\hline & \multirow[t]{2}{*}{$36-50$} & 101 & 43 & 13 & 0 \\
\hline & & $(32.3 \%)$ & $(30.5 \%)$ & $(31.0 \%)$ & - \\
\hline & \multirow[t]{2}{*}{ More than 50} & 29 & 13 & 1 & 0 \\
\hline & & $(9.3 \%)$ & $(9.2 \%)$ & $(2.4 \%)$ & - \\
\hline \multirow[t]{8}{*}{ Work Environment } & Health Insurance Organization & $\begin{array}{l}35 \\
(11.2 \%)\end{array}$ & $\begin{array}{l}21 \\
(14.9 \%)\end{array}$ & $\begin{array}{l}7 \\
(16.7 \%)\end{array}$ & 0 \\
\hline & MOH Hospital & $146(46.6 \%)$ & $\begin{array}{l}64 \\
(45.4 \%)\end{array}$ & $\begin{array}{l}12 \\
(28.6 \%)\end{array}$ & - \\
\hline & Primary Health Clinic & $\begin{array}{l}42 \\
(13.4 \%)\end{array}$ & $\begin{array}{l}12 \\
(8.5 \%)\end{array}$ & 0 & $\begin{array}{l}3 \\
(75.0 \%)\end{array}$ \\
\hline & Private Clinic & $\begin{array}{l}8 \\
(2.6 \%)\end{array}$ & $\begin{array}{l}4 \\
(2.8 \%)\end{array}$ & 0 & $\begin{array}{l}\text { I } \\
(25.0 \%)\end{array}$ \\
\hline & \multirow[t]{2}{*}{ Private Hospital } & 9 & 4 & 5 & 0 \\
\hline & & $(2.9 \%)$ & $(2.8 \%)$ & (11.9\%) & - \\
\hline & \multirow[t]{2}{*}{ University Hospital } & 73 & 36 & 18 & 0 \\
\hline & & $(23.3 \%)$ & $(25.5 \%)$ & $(42.9 \%)$ & - \\
\hline \multirow[t]{10}{*}{ Educational Level } & \multirow[t]{2}{*}{ Bachelor } & 84 & 36 & 14 & 2 \\
\hline & & $(26.8 \%)$ & $(25.5 \%)$ & $(33.3 \%)$ & $(50.0 \%)$ \\
\hline & \multirow[t]{2}{*}{ Diploma } & 51 & 20 & 1 & 1 \\
\hline & & $(16.3 \%)$ & $(14.2 \%)$ & $(2.4 \%)$ & $(25.0 \%)$ \\
\hline & \multirow[t]{2}{*}{ Doctorate } & 33 & 20 & 11 & 0 \\
\hline & & $(10.5 \%)$ & (14.2\%) & $(26.2 \%)$ & - \\
\hline & \multirow[t]{2}{*}{ Fellowship } & 16 & 1 & 1 & 0 \\
\hline & & $(5.1 \%)$ & $(0.7 \%)$ & $(2.4 \%)$ & \\
\hline & \multirow[t]{2}{*}{ Master } & 129 & 64 & 15 & 1 \\
\hline & & $(41.2 \%)$ & $(45.4 \%)$ & $(35.7 \%)$ & $(25.0 \%)$ \\
\hline
\end{tabular}

(Continued) 
Table I (Continued).

\begin{tabular}{|c|c|c|c|c|c|}
\hline \multicolumn{2}{|l|}{ Items } & \multicolumn{4}{|l|}{ Specialty } \\
\hline & & \multirow{2}{*}{$\begin{array}{l}\text { Medical } n=313 \\
81\end{array}$} & \multirow{2}{*}{$\begin{array}{l}\text { Surgery } n=|4| \\
46\end{array}$} & \multirow{2}{*}{$\begin{array}{l}\text { ER and ICU } \mathbf{n = 4 2} \\
15\end{array}$} & \multirow{2}{*}{$\begin{array}{l}\text { Others } n=4 \\
2\end{array}$} \\
\hline Work Experience & $\mathrm{I}-<5$ years & & & & \\
\hline & & $(25.9 \%)$ & $(32.6 \%)$ & $(35.7 \%)$ & $(50.0 \%)$ \\
\hline & $5-10$ years & 101 & 42 & 10 & 1 \\
\hline & & $(32.3 \%)$ & $(29.8 \%)$ & $(23.8 \%)$ & $(25.0 \%)$ \\
\hline & Less than I year & 16 & 2 & 3 & 0 \\
\hline & & $(5.1 \%)$ & $(1.4 \%)$ & $(7.1 \%)$ & - \\
\hline & More than 10 years & 115 & 51 & 14 & I \\
\hline & & $(36.7 \%)$ & $(36.2 \%)$ & $(33.3 \%)$ & $(25.0 \%)$ \\
\hline \multirow{4}{*}{$\begin{array}{l}\text { Did you attend any training/ } \\
\text { educational course for } \\
\text { antibiotics prescription }\end{array}$} & No & 191 & 112 & 27 & 2 \\
\hline & & $(61.0 \%)$ & (79.4\%) & $(64.3 \%)$ & $(50.0 \%)$ \\
\hline & Yes & 122 & 29 & 15 & 2 \\
\hline & & (39.0\%) & $(20.6 \%)$ & $(35.7 \%)$ & $(50.0 \%)$ \\
\hline \multirow{6}{*}{$\begin{array}{l}\text { Your healthcare facility has } \\
\text { an implemented } \\
\text { antimicrobial stewardship } \\
\text { program }\end{array}$} & I do not Know & 114 & 77 & 21 & 4 \\
\hline & & (36.4\%) & $(54.6 \%)$ & $(50.0 \%)$ & $(100.0 \%)$ \\
\hline & No & 112 & 46 & 13 & 0 \\
\hline & & $(35.8 \%)$ & $(32.6 \%)$ & $(31.0 \%)$ & - \\
\hline & Yes & 87 & 18 & 8 & 0 \\
\hline & & $(27.8 \%)$ & $(12.8 \%)$ & $(19.0 \%)$ & - \\
\hline \multirow{6}{*}{$\begin{array}{l}\text { Do you have lists of } \\
\text { antibiotics classified into } \\
\text { "Access, Watch, reserve " } \\
\text { groups in your workplace }\end{array}$} & I do not know & 128 & 71 & 16 & 2 \\
\hline & & $(40.9 \%)$ & (50.4\%) & $(38.1 \%)$ & $(50.0 \%)$ \\
\hline & No & 138 & 58 & 19 & I \\
\hline & & $(44.1 \%)$ & $(41.1 \%)$ & $(45.2 \%)$ & $(25.0 \%)$ \\
\hline & Yes & 47 & 12 & 7 & 1 \\
\hline & & $(15.0 \%)$ & $(8.5 \%)$ & $(16.7 \%)$ & $(25.0 \%)$ \\
\hline
\end{tabular}

Abbreviations: ER; Emergency Room. ICU; Intensive Care Unit. MOH; Ministry of Health.

the cost. ${ }^{3}$ Prescribers may modify their practice only when their attitudes, skills, beliefs and knowledge are integrated with each other potentially resulting in a decrease in antibiotic prescribing which may in turn help reduce the development and spread of infections that are resistant to antibiotics $^{12,13}$ Thus, this study was designed to evaluate knowledge, attitude and practices of Egyptian prescribers.

In the current report, the study population is considered to be representative covering a wide spectrum of the antibiotic prescribers working in different Egyptian healthcare institutes, with different educational and experience standards. Out of the 500 respondents, $(22.6 \%)$ reported they have implemented ASP at their workplace and (13.4\%) have lists of antibiotics classified into "Access, Watch, Reserve" groups. These low rates underscore the need of updated national data about the challenges and barriers in implementing ASP in Egyptian healthcare settings (e.g., shortage of competent microbiology labs, poor knowledge, resistance to change among HCWs, lack of training, lack of financial support). ${ }^{14,15}$ Proper review of exact causes and allocation of resources to increase the implementation coverage could take place. 


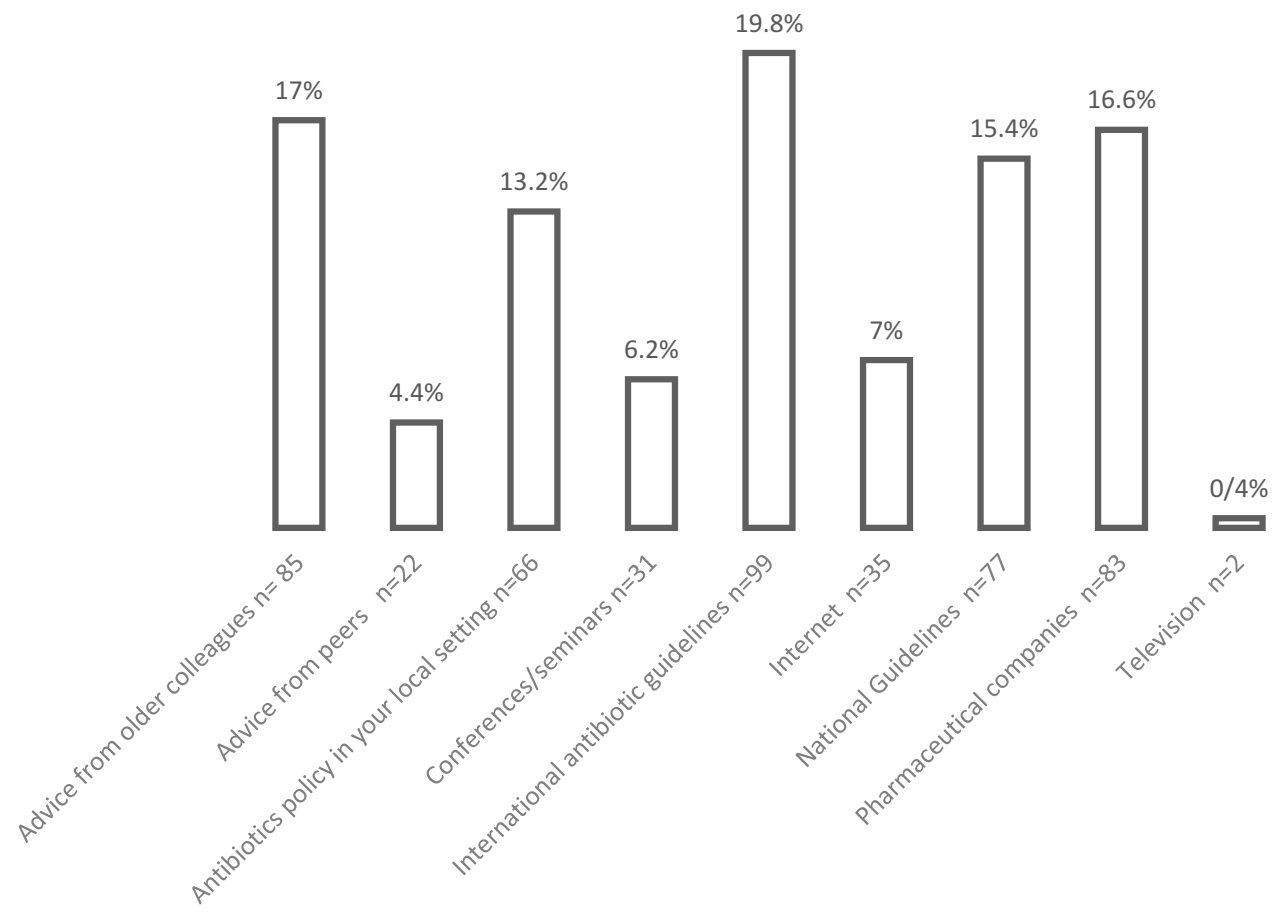

Figure I The main source of information about antibiotic resistance and stewardship.

In low- and middle-income countries, one of the most important factors affecting antimicrobial resistance is the lack of proper training/education of healthcare providers regarding proper antimicrobial use. ${ }^{2}$ Similarly, in Europe, most final-year medical students lacked self-reported preparedness in antibiotic prescribing and desired further education ${ }^{16}$ and a wide variation in the exposure of students in different European countries to important principles of appropriate antibiotic prescribing was observed. ${ }^{17}$ The current report revealed that $(66.4 \%)$ of the participants did not get any training/educational courses about antibiotic prescription, although most of them have completed their postgraduate studies (14.6\% Diploma; $41.8 \%$ Master and $12.8 \%$ Doctorate). This finding raises concerns about the content of current undergraduate, postgraduate and continuous medical educational programs in Egypt and gives clue for the curriculum designers and the medical training providers to consider the inclusion of this vital topic in their courses. Elective courses covering topics like antibiotic prescription and antibiotic stewardship should be designed, delivered by experts and made available for both undergraduate as well as postgraduate candidates.
The presence of an accurate updated source of data about the proper use of antibiotics is crucial. Despite the availability of both national and international guidelines that offer balanced and evidence-based advice for the prescribers, only $(19.8 \%)$ of the participants referred to international antibiotic guidelines as the main source of information about antibiotic resistance and stewardship program versus (15.4\%) who used the national guidelines, and (13.2\%) who used the antibiotics policy in their healthcare setting. Discrepant results were reported from previously published studies; a study from Ireland showed the hospital antibiotic prescribing guidelines as minor source and the dominant influence was the advice of senior doctors. ${ }^{18}$ Krishnakumar and Tsopra, 2019 stated the clinical practice guidelines as the most frequently used resource, followed by antibiotic websites, personal memos, and scientific publications. ${ }^{19}$ By default, the international guidelines should be revised by national and local authorities and adapted to the local clinical needs. Furthermore, the guidelines should proactively address prescribers' concerns. ${ }^{20}$ Further insights are needed to explore the reason for this unacceptable low rate of using the national guidelines and the local antibiotics policy. 
Table 2 Knowledge of Antibiotic Prescribers About Antimicrobial Resistance and Use

\begin{tabular}{|c|c|c|c|}
\hline Item (Correct Answer) & $\begin{array}{l}\text { Yes } \\
\text { No (\%) }\end{array}$ & $\begin{array}{l}\text { No } \\
\text { No (\%) }\end{array}$ & $\begin{array}{l}\text { I Do Not Know } \\
\text { No (\%) }\end{array}$ \\
\hline Antibiotics kill/inhibit pathogenic and commensal bacteria (Yes) & $481(96.2)$ & $16(3.2)$ & $3(0.6)$ \\
\hline Antibiotics kill/inhibit viruses (No) & $20(4)$ & $474(94.8)$ & $6(1.2)$ \\
\hline All cases with coughs, colds and sore throats get improved with the use of antibiotics (No) & $64(12.8)$ & $4 I I(82.2)$ & $25(5)$ \\
\hline Taking antibiotics often has side-effects such as diarrhea (Yes) & $403(80.6)$ & $73(14.6)$ & $24(4.8)$ \\
\hline In Egypt, antibiotics are available for over counter use in pharmacies (Yes) & $394(78.8)$ & $61(12.2)$ & $45(9)$ \\
\hline The efficacy of antibiotic is higher if it is newer or of higher price $(\mathrm{No})$ & $106(21.2)$ & $322(64.4)$ & $40(8)$ \\
\hline The longer the duration of antibiotic use, the better the response ( $\mathrm{No})$ & $115(23)$ & $349(69.8)$ & $36(7.2)$ \\
\hline Overuse of antibiotics makes antibiotics become ineffective (Yes) & $461(92.2)$ & $28(5.6)$ & II (2.2) \\
\hline Bacteria can become resistant to antibiotics (Yes) & $476(95.2)$ & $15(3)$ & $9(1.8)$ \\
\hline Healthy people can carry antibiotics resistant bacteria (Yes) & $451(90.2)$ & $18(3.6)$ & $31(6.2)$ \\
\hline Antibiotics resistance is a worldwide problem: (Yes) & $435(87)$ & $28(5.6)$ & $37(7.4)$ \\
\hline Antibiotics resistance is a problem in Egypt: (yes) & $261(52.2)$ & $149(29.8)$ & $90(18)$ \\
\hline Antibiotics resistant bacteria spread easily from person to person: (Yes) & $241(48.2)$ & $81(16.2)$ & $178(35.6)$ \\
\hline New antibiotics are rapidly solve the problem of resistance: $(\mathrm{No})$ & $253(50.6)$ & $25(5)$ & $222(44.4)$ \\
\hline
\end{tabular}

Meanwhile, the pharmaceutical industry still influences the prescribers' practice by promotional interventions with about $(16 \%)$ of the respondents told that pharmaceutical companies are their main source of information. Faizullah et al 2017 also found similar prescribers' response where the marketing tactics of pharmaceutical industries play an important role in increasing the prescribing and sale of certain drugs. ${ }^{21}$

Successful implementation of antimicrobial stewardship (AMS) programs requires buy-in from relevant clinical stakeholders. A survey of attitudes towards antimicrobial resistance may be useful to determine the level of engagement among clinical stakeholders. ${ }^{22}$

Proper antibiotic use entails the alignment of adequate knowledge, proper practice and a positive attitude. The current report showed an adequate knowledge for (71.6\%) of the participants, a positive attitude for $(9.4 \%)$ of them towards proper antibiotic prescription and (15.6\%) of the participants expressed a proper prescribing practice. Different patterns were published in previous studies; adequate knowledge $(62.8 \%)$, proper practice $(72.9 \%)$ and a positive attitude $(15 \%){ }^{23}$ In a recent single-center Egyptian study, Tahoon et al 2020 reported adequate knowledge (39.3\%), a positive attitude $(85.7 \%)$ and a proper practice $(31.8 \%)$ among the investigated prescribers. ${ }^{9}$ These findings highlight the challenge of making antimicrobial resistance a relevant local issue among clinical stakeholders who are not easily engaged in issues pertaining to antimicrobial use at the hospital. Attitude survey and behavior analysis are highly encouraged to optimize the needed actions to improve the attitude and behavior.

The gap between knowledge, practice and attitude was confirmed in many instances. Tegagn et al 2017 reported most of their study participants do not believe that antibiotics are overused (43\%) and AMR is a great problem in their facility $(35.5 \%), 74.8 \%$ of them disagree on appropriate use of antimicrobial can lead to resistance. Moreover, $31.8 \%$ of HCP believe new antimicrobial development will keep up with the current resistance needed and $57 \%$ of them were disagreed/strongly disagreed on restriction of antibiotics for controlled use. ${ }^{23}$

In their attitudinal survey, Cotta et al 2014 found only around one-third of respondents believed that antimicrobial resistance directly affected patients under their care. ${ }^{22}$ In a previous Egyptian study, data revealed that most healthcare providers recognize that overuse of antibiotics can lead to bacterial antibiotic resistance. Unfortunately, 
Table 3 Attitude of Antibiotic Prescribers Towards Proper Antibiotic Prescription

\begin{tabular}{|c|c|c|c|}
\hline Items & $\begin{array}{l}\text { Strongly Agree/ } \\
\text { Agree } \\
\text { No (\%) }\end{array}$ & $\begin{array}{l}\text { Neutral } \\
\text { No (\%) }\end{array}$ & $\begin{array}{c}\text { Disagree/Strongly } \\
\text { Disagree } \\
\text { No (\%) }\end{array}$ \\
\hline \multicolumn{4}{|l|}{ The following factors increase the antibiotic resistance rates } \\
\hline $\begin{array}{l}\text { - Frequent antibiotic prescription for the same patient } \\
\text { - Frequent use of broad-spectrum antibiotics for the same patient } \\
\text { - The long duration of antibiotic treatment course } \\
\text { - Inappropriate dosing of antibiotics } \\
\text { - Misuse/abuse of antibiotics in livestock and food production } \\
\text { - Patient demand for antibiotics even if it is not indicated } \\
\text { - Poor infection prevention and control practices } \\
\text { - The information delivered from pharmaceutical representatives }\end{array}$ & $\begin{array}{l}356(71.2) \\
349(69.8) \\
297(59.4) \\
396(79.2) \\
298(59.6) \\
\\
386(77.2) \\
397(79.4) \\
307(61.4)\end{array}$ & $\begin{array}{c}50(10) \\
51(10.2) \\
89(17.8) \\
58(11.6) \\
132 \\
(26.4) \\
28(5.6) \\
53(10.6) \\
111 \\
(22.2)\end{array}$ & $\begin{array}{l}94(18.8) \\
100(20) \\
114(22.8) \\
46(24.4) \\
70(14) \\
86(17.2) \\
50(10) \\
82(16.4)\end{array}$ \\
\hline Antibiotics are abused at my workplace & $333(66.6)$ & $55(11)$ & $112(22.4)$ \\
\hline $\begin{array}{l}\text { The antibiotic is chosen according to the availability of the antibiotic more than the microbial cause } \\
\text { of infection }\end{array}$ & $217(43.4)$ & $61(12.2)$ & $192(38.4)$ \\
\hline Antibiotic prescription for patients when they do not need them, does not cause harm & $42(8.4)$ & $25(5)$ & $406(81.2)$ \\
\hline Dispensing antibiotics without prescription should be controlled & $416(83.2)$ & $33(6.6)$ & $51(10.2)$ \\
\hline Available antibiotics in the Egyptian market are of bad quality & $192(38.4)$ & $\begin{array}{c}131 \\
(26.2)\end{array}$ & $177(35.4)$ \\
\hline I want to attend a training program for antibiotics prescription & $404(80.8)$ & $38(7)$ & $58(11.6)$ \\
\hline It is important to know the resistance rates in my workplace & $434(86.8)$ & $24(4.8)$ & $42(8.4)$ \\
\hline International guidelines are more important than local policies in antibiotic prescription & $215(43)$ & $98(19.6)$ & $187(37.4)$ \\
\hline Some antibiotics must be ordered only by a qualified senior physician & $421(84.2)$ & $30(6)$ & $49(9.8)$ \\
\hline
\end{tabular}

because of the lack of access to microbiological testing, physicians may under-appreciate the prevalence of resistant bacterial infections. ${ }^{24}$ In the United States, Giblin et al 2004 reported almost $95 \%$ of clinicians surveyed agreed that AMR was a national problem, although they were significantly less likely to perceive AMR to be a problem in their own institution or own practice. ${ }^{13}$ European prescribers who showed a broad awareness of AMR and its importance, with $95 \%$ agreeing AMR was a national problem. Yet fewer (63\%) believed it had an impact on their own practice. They attributed the cause of AMR to pharmaceutical companies, veterinarians and poor infection control practices. $^{25}$

The present study stated a significant positive correlation between knowledge and attitude and a significant positive correlation between knowledge and practice. The implementation of stewardship programs and the delivery of training course significantly affect the knowledge with no statistically significant effect on the attitude. Hence, the training/educational programs should be properly designed to target the 3 learning domains: knowledge, skills and attitude. The deficiency of role models and success stories may explain this finding. A review of the design of training/education strategies, available courses, their frequency and the implementation method is highly recommended. We have to keep in mind that the time needed to change attitude is far more than that needed to give the same audience the targeted knowledge.

\section{Limitation of Study}

The specialty of physicians has an impact on their prescribing behaviors. However, in this survey, we could not analyze the features and underlying differences between all participating specialties. Further detailed studies are warranted.

\section{Conclusion}

Egyptian prescribers have a good level of knowledge about antibiotics however low levels of positive attitude and proper 


\section{Antibiotic prescritpion steps}

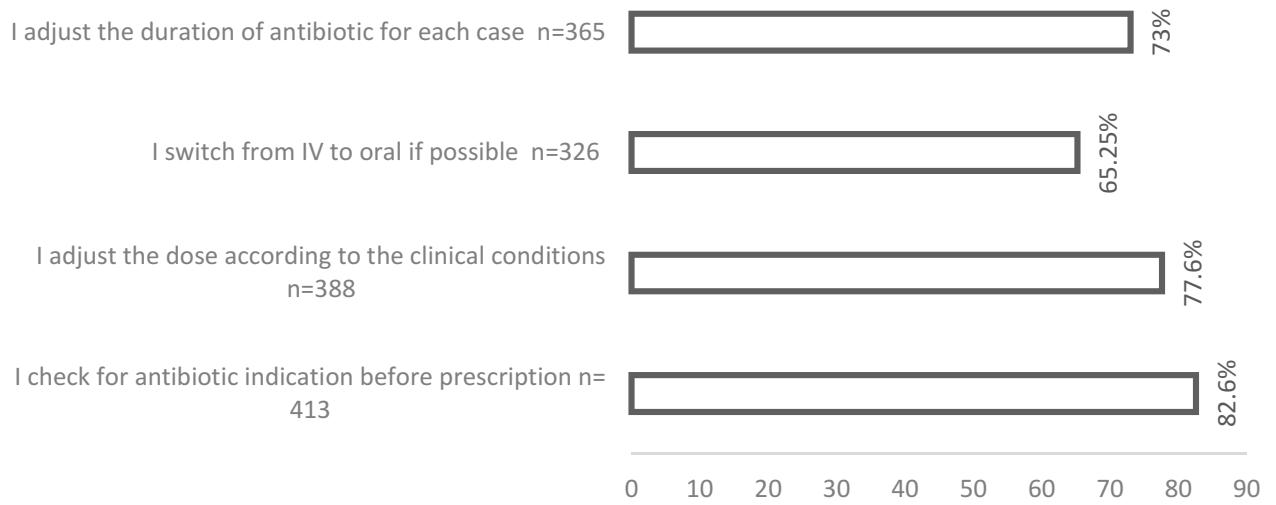

Figure 2 Prescribers practice in Antibiotic prescription.

practice towards the problem of AMR are reported. Elder, more experienced and trained prescribers showed more proper practice. The implementation of antimicrobial stewardship program and using proper sources of information were significantly associated with adequate practice. Knowledge is positively correlated with both attitude and practice.

An updated national data about challenges and barriers in implementing ASP in Egyptian healthcare settings is needed. Using regional antibiogram may be the solution for shortage of competent microbiology labs in Egyptian healthcare settings. Review of the current undergraduate, postgraduate and continuous medical educational programs in Egypt is warranted. Elective courses covering topics like antibiotic prescription and antibiotic stewardship should be designed. Attitude survey and behavior analysis are highly encouraged to optimize the needed actions to improve the attitude and behavior.

\section{Acknowledgments}

We acknowledge the help in data collection offered by Dr. Weam Mohammed, director of Infection prevention and control department, health Affairs directorate, BeniSuef, Egypt; Dr. Heba Kasem Ahmed, Director of Infection Prevention and Control Department, Health Affairs Directorate, Cairo, Egypt; Dr. Mona AbdelGaleel, head of infection control team, El-Mahala General Hospital Gharbia, Egypt; Dr. Hanan Sayed Abd El-Razek, Director of infection prevention and control department, Health affairs directorate, Minya, Egypt; Dr. Omnia Sameh Habib, Infection Prevention and control consultant, Boulak El-Dakroor General Hospital, Giza, Egypt; Dr. Mai Ezz El-Din Abo Samra, Infection control manager, Health care authority, Universal Health Insurance, Port Said Branch Port Said, Egypt. Dr. Ahmed Sayed Mosa, Director of Infection Prevention and Control department, Health Affairs directorate, Assiut, Egypt.

\section{Disclosure}

The authors report no conflicts of interest in this work.

\section{References}

1. L'or C, Bjerrum L. Antimicrobial resistance: risk associated with antibiotic overuse and initiatives to reduce the problem. Ther $A d v$ Drug Saf. 2014;5(6):229-241. doi:10.1177/2042098614554919

2. World Health Organization. The world medicines situation; 2011. Available from: https://www.who.int/medicines/areas/policy/world medicines_situation/WMS_ch6_wPricing_v6.pdf. Accessed November 24, 2020.

3. Buke C, Hosgor-Limoncu M, Ermertcan S, et al. Irrational use of antibiotics among university students. $J$ Infect. 2005;51(2):135-139. doi:10.1016/j.jinf.2004.12.001

4. Hart CA, Kariuki S. Antimicrobial resistance in developing countries. BMJ. 1998;317(7159):647-650. doi:10.1136/bmj.317.7159.647

5. Gebeyehu E, Bantie L, Azage M. Inappropriate use of antibiotics and its associated factors among Urban and Rural Communities of Bahir Dar City Administration, Northwest Ethiopia. PLoS One. 2015;10(9): e0138179. doi:10.1371/journal.pone.0138179

6. Dyar OJ, Beović B, Vlahović-Palčevski V, Verheij T, Pulcini C. How can we improve antibiotic prescribing in primary care? Expert Rev Anti Infect Ther. 2016;14:403-413. doi:10.1586/14787210.2016.1151353

7. World Health Organization. The evolving threat of antimicrobial resistance-options for action; 2012. Available from: https://apps. who.int/iris/handle/10665/44812. Accessed November 24, 2020.

8. El Sherbiny NA, Ibrahim EH, Masoud M. Assessment of knowledge, attitude and behavior towards antibiotic use in primary health care patients in Fayoum Governorate, Egypt. Alexandria J Med. 2018;54 (4):535-540. doi:10.1016/j.ajme.2018.06.001

9. Tahoon MA, Khalil MM, Hammad E, Morad WS, Wad SM, Ezzat S. The effect of educational intervention on healthcare providers' knowledge, attitude, \& practice towards antimicrobial stewardship program at National Liver Institute, Egypt. Egypt Liver J. 2020;10:5. doi:10.1186/s43066-019-0016-5 
10. Assar A, Abdelraoof MI, Abdel-Maboud M, et al. Knowledge, attitudes, and practices of Egypt's future physicians towards antimicrobial resistance (KAP-AMR study): a multicenter cross-sectional study. Environ Sci Pollut Res Int. 2020;27(17):21292-21298. doi:10.1007/s11356-020-08534-5

11. Koo H-C, Poh BK, Ruzita AT. Assessment of knowledge, attitude and practice towards whole grains among children aged 10 and 11 years in Kuala Lumpur. Malaysia Int J Food. 2015.

12. Wester CW, Durairaj L, Evans AT, Schwartz DN, Husain S, Martinez E. Antibiotic resistance: a survey of physician perceptions. Arch Intern Med. 2002;162(19):2210-2216. doi:10.1001/archinte.162.19.2210

13. Giblin TB, Sinkowitz-Cochran RL, Harris PL, et al. Clinicians' perceptions of the problem of antimicrobial resistance in health care facilities. Arch Intern Med. 2004;164:1662-1668. doi:10.1001/ archinte.164.15.1662

14. Azzab MM, El Sokkary RH, Tawfeek MM, Gebriel MG. Multidrugresistant bacteria among patients with ventilator-associated pneumonia in an emergency intensive care unit, Egypt. EMHJ. 2016;22 (12):894-903. doi:10.26719/2016.22.12.894

15. El-Sokkary RH, Negm EM, Othman HA, Tawfeek MM, Metwally WS. Stewardship actions for device associated infections: an intervention study in the emergency intensive care unit. $J$ Infect Public Health. 2020;13(12):1927-1931. doi:10.1016/j. jiph.2020.10.003

16. Dyar OJ, Nathwani D, Monnet DL, et al. Do medical students feel prepared to prescribe antibiotics responsibly? Results from a cross-sectional survey in 29 European countries. J Antimicrob Chemother. 2018;73(8):2236-2242. doi:10.1093/jac/dky150

17. Pulcini C, Wencker F, Frimodt-Moller N, Kern WV, Nathwani D, Rodríguez-Baño J; ESGAP Curriculum Working Group. European survey on principles of prudent antibiotic prescribing teaching in undergraduate students. Clin Microbiol Infect. 2015;21:354-361. doi:10.1016/j. cmi.2014.11.015
18. De Souza V, MacFarlane A, Murphy AW, Hanahoe B, Barber A, Cormican M. A qualitative study of factors influencing antimicrobial prescribing by non-consultant hospital doctors. $J$ Antimicrob Chemother. 2006;58:840-843. doi:10.1093/jac/dk1323

19. Krishnakumar J, Tsopra R. What rationale do GPs use to choose a particular antibiotic for a specific clinical situation? BMC Fam Pract. 2019;20:178. doi:10.1186/s12875-019-1068-7

20. Tonkin-Crine S, Yardley L, Coenen S, et al. Strategies to promote prudent antibiotic use: exploring the views of professionals who develop and implement guidelines and interventions. Fam Pract. 2013;30:88-95. doi:10.1093/fampra/cms043

21. Faizullah M, Rahman N, Umar MI, Anwar M, Sarfraz M. A cross-sectional study on knowledge, attitude and practices of medical doctors towards antibiotic prescribing patterns and resistance in Khyber Pakhtun Khawah, Pakistan. J App Pharm Sci. 2017;7 (12):38-46.

22. Cotta MO, Robertson MS, Tacey M, et al. Attitudes towards antimicrobial stewardship: results from a large private hospital in Australia. Health Infect. 2014;19:89-94. doi:10.1071/HI14008

23. Tegagn GT, Yadesa TM, Ahmed Y. Knowledge, attitudes and practices of healthcare professionals towards antimicrobial stewardship and their predictors in Fitche Hospital. $J$ Bioanal Biomed. 2017;9:091-097. doi:10.4172/1948-593X.1000159

24. Dooling KL, Kandeel A, Hicks LA, et al. Understanding antibiotic use in minya district, egypt: physician and pharmacist prescribing and the factors influencing their practices. Antibiotics. 2014;3 (2):233-243. doi:10.3390/antibiotics302023

25. Pulcini C, Williams F, Molinari N, Davey P, Nathwani D. Junior doctors' knowledge and perceptions of antibiotic resistance and prescribing: a survey in France and Scotland. Clin Microbiol Infect. 2011;17(1):80-87. doi:10.1111/j.1469-0691.2010.03179
Infection and Drug Resistance

\section{Publish your work in this journal}

Infection and Drug Resistance is an international, peer-reviewed openaccess journal that focuses on the optimal treatment of infection (bacterial, fungal and viral) and the development and institution of preventive strategies to minimize the development and spread of resistance. The journal is specifically concerned with the epidemiology of antibiotic resistance and the mechanisms of resistance development and diffusion in both hospitals and the community. The manuscript management system is completely online and includes a very quick and fair peerreview system, which is all easy to use. Visit http://www.dovepress.com/ testimonials.php to read real quotes from published authors. 